\title{
Use of Inter-Simple Sequence Repeats and Amplified Fragment Length Polymorphisms to Analyze Genetic Relationships Among Small Grain-Infecting Species of Ustilago
}

\author{
J. G. Menzies, G. Bakkeren, F. Matheson, J. D. Procunier, and S. Woods
}

First, third, fourth, and fifth authors: Cereal Research Centre, Agriculture and Agri-Food Canada, 195 Dafoe Road, Winnipeg, MB, Canada, R3T 2M9; and second author: Pacific Agri-Food Research Centre, Agriculture and Agri-Food Canada, Highway 97, Summerland, BC, Canada, V0H $1 \mathrm{ZO}$.

Accepted for publication 23 September 2002.

\begin{abstract}
Menzies, J. G., Bakkeren, G., Matheson, F., Procunier, J. D., and Woods, S. 2003. Use of inter-simple sequence repeats and amplified fragment length polymorphisms to analyze genetic relationships among small grain-infecting species of Ustilago. Phytopathology 93:167-175.

In the smut fungi, few features are available for use as taxonomic criteria (spore size, shape, morphology, germination type, and host range). DNA-based molecular techniques are useful in expanding the traits considered in determining relationships among these fungi. We examined the phylogenetic relationships among seven species of Ustilago (U. avenae, U. bullata, U. hordei, U. kolleri, U. nigra, U. nuda, and $U$. tritici) using inter-simple sequence repeats (ISSRs) and amplified

fragment length polymorphisms (AFLPs) to compare their DNA profiles. Fifty-four isolates of different Ustilago spp. were analyzed using ISSR primers, and 16 isolates of Ustilago were studied using AFLP primers. The variability among isolates within species was low for all species except $U$. bullata. The isolates of $U$. bullata, $U$. nuda, and $U$. tritici were well separated and our data supports their speciation. $U$. avenae and $U$. kolleri isolates did not separate from each other and there was little variability between these species. U. hordei and U. nigra isolates also showed little variability between species, but the isolates from each species grouped together. Our data suggest that $U$. avenae and $U$. koller $i$ are monophyletic and should be considered one species, as should $U$. hordei and U. nigra.
\end{abstract}

The parasitic species of the genus Ustilago which cause the smut diseases of barley, oat, and wheat traditionally have been classified using characteristics such as spore size, shape, morphology, and germination, and, to a lesser extent, host range. Although these characteristics are useful and relatively easy to work with, a system of classification which attracts general consensus among the people who work with these fungi has been illusive. Stevenson and Johnson (41) proposed a system in which the loose smuts with embryo infection and mycelial germination are classified as $U$. nuda (Jensen) Kellerm. \& Swingle on barley and U. tritici (Pers.) Rostr., on wheat; the seedling-infecting species with sporidial germination and echinulate spores are classified as $U$. avenae (Pers.) Rostr. on oat and $U$. nigra Tapke (syn. U. avenae (Pers.) Rostr.) on barley; and those with smooth spores are classified as $U$. kolleri Wille (syn. U. hordei (Pers.) Lagerh.) on oat and $U$. hordei (Pers.) Lagerh. on barley. This has been popular among plant pathologists likely because it reflects the ease of determining the different species (simple spore morphology and germination tests) and the convenience of the pathogen species aligning with the host plant. However, the very simplicity of this system does not ensure its accuracy. Fischer and Shaw (15) and Vánky (45) have warned that, because there are comparatively few morphological features available as taxonomic criteria, it is difficult to draw conclusions about relationships within smut fungi and between smut fungi and other groups. In addition, Fischer (14) warns about putting too much emphasis on the host plant in the classification

Corresponding author: J. G. Menzies; E-mail address: jmenzies@agr.gc.ca

Publication no. P-2002-1205-01R

This article is in the public domain and not copyrightable. It may be freely reprinted with customary crediting of the source. The American Phytopathological Society, 2003 of these fungi, while disregarding the actual characteristics of the fungi. It is recognized that knowledge of many characteristics is needed to establish relationships among these fungi (45), including the biological relationships between the species of Ustilago (32).

In attempting to gain more knowledge about the relationships among the different species of Ustilago, researchers have expanded the traits that are considered in classification. In other studies on the morphology of the smuts, Bauer et al. (6) used electron microscopy and studied the differences in hyphal septation and zones of host-parasite interactions to identify monophyletic groups within the smut fungi and allied taxa. Their results were useful in sorting out some relationships at the order and genus levels, but were not as helpful at the species level. Other researchers have studied the ability of the different Ustilago spp. to successfully hybridize. Distinction has to be made between intercompatibility and fecundity. Intercompatibility is revealed in petri dish mating assays where quite different species readily fuse because of compatible mating type factors such as promiscuous pheromone and pheromone receptors. However, often no teliospores will be formed on (common) host plants. In certain combinations, some $F_{1}$ teliospores will be formed that are incapable of germinating. Hybridization ranges from the formation of such teliospores which, when germinating, will produce haploid basidiospores that subsequently lyse to a degree related to the degree of relatedness of the parents, to fecundity defined as true hybridization producing fertile $F_{1}$ haplonts (33). Hybridization studies were pioneered by Hanna and Popp (18) and Holton (20) using $U$. avenae and $U$. kolleri and summarized by Nielsen (36). It appears that, in the species $U$. nuda, U. tritici, U. hordei, U. nigra, $U$. avenae, U. kolleri, U. bullata Berk. in Hook., U. aegilopsidis Picbauer, $U$. phrygica Magnus, and $U$. turcomanica Tranzschel ex $\mathrm{K}$. Vánky, the mating of haplonts is controlled by a bipolar mating 
system. The lines having mating type 1 (MAT-1, formerly called a) $(3,4)$ of any of these species are compatible and will form infective dikaryons with lines having mating type 2 (MAT-2, formerly called $A$ ) $(3,4)$ of any other of the species. Two common hosts have been described which allow the production of teliospores (32). It is important to realize, however, that there can be a low compatibility between certain collections or races within a species of Ustilago such as $U$. bullata (24) and $U$. tritici (33). Nielsen (33) suggested that the low compatibility between some isolates

TABLE 1. Fifty-four isolates of Ustilago spp. used for inter-simple sequence repeats (ISSR) analysis

\begin{tabular}{|c|c|c|}
\hline Isolate no. & Ustilago spp. & Origin \\
\hline 4 & U. nuda & Italy, 1997 \\
\hline 6 & U. nuda & Lacombe, Alberta, Canada, 1996 \\
\hline 7 & U. nuda & Tyndall, Manitoba, Canada, 1997 \\
\hline 8 & U. nuda & Ontario, Canada, 1995 \\
\hline 9 & U. nuda & Ontario, Canada, 1995 \\
\hline 11 & U. nigra & Morden, Manitoba, Canada, 1997 \\
\hline $12^{\mathrm{a}}$ & U. nigra & The former USSR \\
\hline $13^{\mathrm{a}}$ & U. nigra & The former USSR \\
\hline 14 & U. nigra & Gimili, Manitoba, Canada, 1997 \\
\hline 15 & U. nigra & Binscarth, Manitoba, Canada, 1997 \\
\hline 16 & U. nigra & Gimili, Manitoba, Canada, 1985 \\
\hline 17 & U. nigra & Canada \\
\hline $18^{\mathrm{a}}$ & U. nigra & Winnipeg, Manitoba, Canada, 1996 \\
\hline $21^{\mathrm{a}}$ & U. hordei & Morden, Manitoba, Canada, 1997 \\
\hline $22^{\mathrm{a}}$ & U. hordei & Edran, Manitoba, Canada, 1997 \\
\hline $23^{\mathrm{a}}$ & U. hordei & Kenya \\
\hline $24^{\mathrm{a}}$ & U. hordei & Turkey \\
\hline 25 & U. hordei & Kenya \\
\hline 26 & U. hordei & Ethiopia \\
\hline 27 & U. hordei & Portugal \\
\hline $28^{\mathrm{a}}$ & U. hordei & Canada \\
\hline 29 & U. hordei & South Australia \\
\hline 30 & U. hordei & Iran \\
\hline 31 & U. tritici & Canada $\left(\right.$ Race T2) ${ }^{\mathrm{b}}$ \\
\hline 32 & U. tritici & Argentina (Race T12) ${ }^{\mathrm{b}}$ \\
\hline 33 & U. tritici & Czechoslovakia (Race T9) ${ }^{b}$ \\
\hline $34^{\mathrm{a}}$ & U. tritici & Turkey (Race T26) ${ }^{\mathrm{b}}$ \\
\hline 35 & U. tritici & Canada (Race T33) ${ }^{b}$ \\
\hline $36^{\mathrm{a}}$ & U. tritici & China $(\text { Race } 37)^{\mathrm{b}}$ \\
\hline $38^{\mathrm{a}}$ & U. tritici & Israel (Race T38) \\
\hline 39 & U. tritici & Tunisia (Race T14) ${ }^{\mathrm{b}}$ \\
\hline $40^{\mathrm{a}}$ & U. tritici & Melita, Manitoba, Canada, 1997 \\
\hline $41^{\mathrm{a}}$ & U. avenae & Creelman, Saskatchewan, Canada 1973 \\
\hline 42 & U. avenae & United States of America ${ }^{c}$ \\
\hline 43 & U. avenae & United States of America ${ }^{c}$ \\
\hline $44^{\mathrm{a}}$ & U. avenae & Canada \\
\hline 45 & U. avenae & Canada \\
\hline 46 & U. avenae & Europe, 1992 \\
\hline $47^{\mathrm{a}}$ & U. avenae & Europe, 1992 \\
\hline 48 & U. avenae & United States of America ${ }^{c}$ \\
\hline 51 & U. kolleri & Morden, Manitoba, Canada, 1997 \\
\hline 52 & U. kolleri & Bolivia, 1991 \\
\hline 54 & U. kolleri & Vinton, Quebec, Canada 1945 \\
\hline 55 & U. kolleri & Olhao, Portugal, 1980 \\
\hline 56 & U. kolleri & South-West Turkey \\
\hline $57^{\mathrm{a}}$ & U. kolleri & Kapunda, Australia, 1978 \\
\hline $58^{\mathrm{a}}$ & U. kolleri & 1977 \\
\hline $59^{a}$ & U. kolleri & 1974 \\
\hline $60^{\mathrm{a}}$ & U. kolleri & Melfort, Saskatchewan, Canada, 1997 \\
\hline $69^{d}$ & U. bullata & Golden Prairie, Saskatchewan, Canada \\
\hline $70^{\mathrm{d}}$ & U. bullata & Piapot, Saskatchewan, Canada \\
\hline $71^{d}$ & U. bullata & Meadow Lake, Saskatchewan, Canada \\
\hline $72^{d}$ & U. bullata & Nipawin, Saskatchewan, Canada \\
\hline $73^{d}$ & U. bullata & Tisdale, Saskatchewan, Canada \\
\hline
\end{tabular}

${ }^{a}$ These 19 isolates were studied using 7 ISSR primers, but the other 35 isolates were studied using all 11 primers.

${ }^{b}$ Described by Nielsen (35).

${ }^{\mathrm{c}}$ Represents three different races provided by C. S. Holton to J. Nielsen, CRC, AAFC in 1968.

${ }^{\mathrm{d}}$ Ub69 and Ub70 were isolated from Downy Brome (Bromus tectorum L.), Ub71 and Ub73 were isolated from Foxtail Barley (Hordeum jubatum L.), and Ub72 was isolated from Meadow Brome (B. riparius Rehmann). or races is probably caused by evolution during long-term association with host populations. This also may explain some of the karyotype differences observed among isolates within a species. These studies of interspecific hybridization, combined with studies of the inheritance of certain traits between species such as virulence genes (16) and spore shape $(29,43)$, were useful in demonstrating how closely related some of these "species" appear to be.

The electrophoretic analysis of proteins also has been useful in studying the relationships of the different Ustilago spp. Bradford et al. (10) examined 14 species of Ustilago with graminaceous and nongraminaceous hosts using gel electrophoresis. They found that they could not characterize species using $\alpha$-esterase, phosphatase, and leucine aminopeptidase zymograms, but the leucine aminopeptidase zymograms were similar for graminaceous smuts. Kim et al. (23) studied detergent soluble polypeptides separated by two-dimensional isoelectric-focusing polyacrylamide gel electrophoresis for six different smut species. They found that $U$. nuda and $U$. tritici differed greatly in their polypeptide composition and $U$. nigra, $U$. hordei, $U$. avenae, and $U$. kolleri differed very little.

The use of DNA-based molecular techniques to examine relationships within and among different fungi at the species, subspecies, forma specialis, and race levels also has been applied to the smut fungi in recent years. Blanz and Gottschalk (9) studied the 5S ribosomal RNA nucleotide sequences and Begerow et al. (8) studied the ribosomal DNA sequences of some smut fungi and related taxa, including some different species of Ustilago. They were mostly concerned with determining the appropriateness of the different genera of smuts in taxonomic orders. They demonstrated that these techniques can be useful in helping to understand genetic relationships among the different smut species. Bakkeren et al. (5) compared the use of DNA sequences from the genomic internal transcribed spacer (ITS) ribosomal RNA region with the amplified fragment length polymorphism (AFLP) technique while examining phylogenetic relationships among the cereal- and grass-infecting Ustilago spp. They found that, when comparing five geographic isolates of $U$. hordei and individual isolates of related species, it was difficult to distinguish isolates and some related species using the ITS sequences, but the $U$. hordei isolates were well separated from the different species isolates when using AFLP fingerprints. The AFLP technique, which is based on the selective polymerase chain reaction (PCR) amplification of restriction fragments from a total digest of genomic DNA, is highly sensitive to differences in DNA sequences and can provide more information on variation than any other molecular technique (26). The genetic relationships among different species of bunt fungi (Tilletia spp.) also have been examined using molecular techniques such as random amplified polymorphic DNA (RAPD) $(17,40)$, the random fragment length polymorphism (RFLP) analysis of the 5.8S rRNA and the ITS region (40), and AFLP (A. Laroche and G. Bakkeren, unpublished data).

Inter-simple sequence repeats (ISSRs) have been used as another method to characterize genetic variation within fungi but, to date, not with the smut fungi. This technique was first demonstrated as a technique for measuring genetic diversity in plants and animals by Zietkiewicz et al. (47) and then shown by Hantula et al. (19) to be able to generate DNA markers in a variety of fungi as well. This technique using primers containing microsatellite sequences and degenerate anchors at the $5^{\prime}$ end, is highly reproducible, allows detection of interspecific and intraspecific DNApolymorphisms, and is applicable to a diverse range of fungal species (19). The work of Hanulta et al. (19) supported the hypothesis that there would be a greater likelihood of finding polymorphisms with ISSRs (referred to as RAMS in their work) than with most other techniques, including RAPDs, because the evolutionary rate within ISSRs is considerably higher than in most other types of DNA (11). Hanulta et al. (19) also found that ISSRs are common in Ustilago genomes by conducting a computer search on all available Ustilago sequences. 
The objective of this work was to use ISSRs to generate DNA profiles of different isolates of seven species of Ustilago to examine the phylogenetic relationships among this group of small grain-infecting fungi. Previous work by Bakkeren et al. (5) indicated that $U$. nigra and $U$. hordei are very closely related; therefore, to more closely examine this relationship, apart from the ISSR experiments, the AFLP technique was employed to study the phylogenetic relationship between $U$. nigra and U. hordei.

\section{MATERIALS AND METHODS}

Fungal isolates. ISSRs from 54 isolates of different Ustilago spp. were amplified using anchored ISSR primers (Table 1). The species studied included $U$. nuda, U. nigra, U. hordei, U. tritici, $U$. avenae, $U$. kolleri, and $U$. bullata (the $U$. bullata isolates were provided by B. Gossen, AAFC, Saskatoon, SK, Canada). A pure culture of each isolate was obtained by streaking teliospores onto half-strength potato dextrose with $2 \%$ agar (0.5 PDA) and incubating them for $24 \mathrm{~h}$ to allow them to germinate. Single germinated teliospores were isolated and transferred to fresh 0.5 PDA. Pure cultures were maintained at $4^{\circ} \mathrm{C}$.

To prepare fungal cells for DNA extraction, a loop of cells from the 0.5 PDA was inoculated into $15 \mathrm{ml}$ of sterile Ustilago medium (2) and incubated in shake culture $(200 \mathrm{rpm})$ at $22^{\circ} \mathrm{C}$ for 5 to 7 days. After incubation, the culture was transferred to $15-\mathrm{ml}$ sterile centrifuge tubes, centrifuged at $2,300 \times g$ for $20 \mathrm{~min}$, and the liquid decanted. The pellet was washed twice with $9 \mathrm{ml}$ of sterile distilled water, mixing with a vortex and recentrifugation. The cells were frozen at $-20^{\circ} \mathrm{C}$ until lyophilized. Lyophilized cells were stored at $-70^{\circ} \mathrm{C}$.

DNA extraction. DNA extraction was conducted using a modified procedure from Kim et al. (22). The lyophilized pellet was broken apart using a sterile glass rod under sterile conditions. To each tube, $2 \mathrm{ml}$ of $3-\mathrm{mm}$ glass beads and $1 \mathrm{ml}$ of sterile sand (both prewashed with $\mathrm{HCl}$ ) were added and shaken on a paint shaker for $3 \mathrm{~min}$. After shaking, $6 \mathrm{ml}$ of extraction buffer $(1.0 \mathrm{M}$ Tris- $\mathrm{HCl}, \mathrm{pH}$ 8.7, 0.5 M EDTA, $\mathrm{pH} 8.0,5.0 \mathrm{M} \mathrm{NaCl}$, and $10 \%$ cetyltrimethylammonium bromide) and Proteinase $\mathrm{K}$ at $50 \mu \mathrm{g} / \mathrm{ml}$ (10 $\mathrm{mg} / \mathrm{ml}$ in TE [10 mm Tris-HCl, $1 \mathrm{~mm}$ EDTA, $\mathrm{pH} \mathrm{7.6])}$ (Boehringer Mannheim) (lyophilizate at $\approx 20$ units $/ \mathrm{mg}$ at $37^{\circ} \mathrm{C}$ with hemoglobin as substrate; 1 unit is the enzyme activity which liberates in 1 min Folin-positive amino acids and peptides corresponding to $1 \mu \mathrm{mol}$ tyrosine) were added. The tubes were inverted and gently shaken to mix the extraction buffer and pellet, followed by $10 \mathrm{~s}$ on a vortex machine. After mixing, sodium dodecyl sulfate was added to a final concentration of $1 \%$ and then the tubes were placed in a water bath at $65^{\circ} \mathrm{C}$ for $2 \mathrm{~h}$, with a gentle shaking of the tube every $0.5 \mathrm{~h}$. After cooling to $30^{\circ} \mathrm{C}, 6 \mathrm{ml}$ of chloroform/ isoamyl alcohol (24:1) was added and the tubes were incubated on an orbital shaker $(60 \mathrm{rpm})$ at room temperature for $20 \mathrm{~min}$. The tubes were then centrifuged at 2,300 $\times g$ for $20 \mathrm{~min}$, after which the supernatant was transferred to a clean $15-\mathrm{ml}$ centrifuge tube. Isopropanol $(0.6 \mathrm{vol})$ was added and the solution slowly mixed by gentle inversion to precipitate the DNA. The DNA pellet was then obtained by centrifugation for $1 \mathrm{~min}$ at $2,300 \times g$ and the supernatant decanted off. Five milliliters of $70 \%$ ETOH was added to the tube, at which point the DNA pellet was stored at $4^{\circ} \mathrm{C}$.

The DNA pellet then was dissolved in $1.3 \mathrm{ml}$ of sterile water and $0.5 \mathrm{ml}$ of $5 \times$ TE was added along with RNAse (Sigma, $4.3 \mathrm{~K}$ units $/ \mathrm{ml}$ of solution) to a final concentration of $50 \mu \mathrm{g} / \mathrm{ml}$ of solution. The suspension was gently mixed by inversion, centrifuged for $20 \mathrm{~s}$ at $2,300 \times g$ and then incubated for $1.5 \mathrm{~h}$ in a water bath at $37^{\circ} \mathrm{C}$. The suspension was transferred to a microcentrifuge tube $(2.0 \mathrm{ml})$ containing $900 \mu \mathrm{l}$ of DNA solution and $350 \mu \mathrm{l}$ of buffered phenol. The solution was gently mixed by inversion for $1 \mathrm{~min}$, centrifuged at $2,300 \times g$ for $20 \mathrm{~s}$, and $350 \mu \mathrm{l}$ of chloroform/ isoamyl alcohol $(24: 1)$ was added to the supernatant. The tubes were mixed again by inversion for $1 \mathrm{~min}$ and recentrifuged at $2,300 \times g$ for $10 \mathrm{~min}$. The supernatant was transferred to clean tubes containing $700 \mu \mathrm{l}$ of chloroform/isoamyl alcohol (24:1) mixed by inversion for $1 \mathrm{~min}$ and then centrifuged at 2,300 $\times g$ for $10 \mathrm{~min}$. The supernatant was collected in a clean $15-\mathrm{ml}$ tube.

The DNA was precipitated by adding $1 / 10$ vol of a $3 \mathrm{M} \mathrm{NaCl}$ solution and $2.5 \mathrm{vol}$ of $75 \%$ ethanol. After centrifugation, the DNA pellet was washed three times with $70 \%$ ethanol, dried, and resuspended in sterile OPTIMA water (Fisher Scientific, Fair Lawn, NJ). Estimates of DNA concentration were obtained by $A_{260}$ measurements using an Ultrospec 3000 (Amersham Pharmacia Biotech, Baie de Urfé, QC, Canada). Working solutions of PCR-ready DNA were diluted to a concentration of $20 \mathrm{ng} / \mu \mathrm{l}$ using sterile OPTIMA water.

ISSR amplification and electrophoresis. The DNA samples underwent Hot Start PCR following the methods of Procunier et al. (38). The PCR was carried out for 35 cycles in an MJ1 thermal cycler (MJ Research, Watertown, MA). In the cycle program, the annealing temperature was modified for specific primers (Table 2).

Gel electrophoresis was carried out using standard protocols. When scoring the gels, the presence of a particular band was given the value of 1 whereas the absence of this band was scored as 0 .

AFLP analysis. A second set of experiments was conducted to examine more closely the relationship between $U$. nigra and $U$. hordei using AFLP primers. In these experiments, 16 singlebasidiospore smut isolates were studied, of which 5 were $U$. hordei and 7 were U. nigra; and 1 each of U. aegilopsidis, $U$. avenae, $U$. kolleri, and $U$. nuda were added as control isolates (Table 3). DNA template preparation and AFLP analysis were conducted as described in Bakkeren et al. (5). No preamplification was performed. PCR reactions were performed on BamHI/Mse1 templates using primer combinations BamPat + MsePa.FAM, BamPat + MsePt.JOE, BamPaa + MsePt.JOE, and BamPaa + MsePc.FAM, whereby the lowercase letters denote the specifying nucleotides for Bam+2 and Mse+1, respectively, and 6-FAM and JOE are fluorophores. Primers were custom made by Applied Biosystems (Foster City, CA). PCR reactions were run on a 96well TwinBlock System (Ericomp) using the following touchdown profile: cycle $1=3 \mathrm{~min}$ at $94^{\circ} \mathrm{C}, 30 \mathrm{~s}$ at $65^{\circ} \mathrm{C}$, and $2 \mathrm{~min}$ at $72^{\circ} \mathrm{C}$; cycles 2 to $9=1 \mathrm{~min}$ at $94^{\circ} \mathrm{C} ; 30 \mathrm{~s}$ at $64^{\circ} \mathrm{C}$ (lowering the annealing temperature each cycle by $\left.1^{\circ}\right) ; 2$ min at $72^{\circ} \mathrm{C} ; 23$ cycles of $1 \mathrm{~min}$ at $94^{\circ} \mathrm{C}, 30 \mathrm{~s}$ at $56^{\circ} \mathrm{C}$, and $2 \mathrm{~min}$ at $72^{\circ} \mathrm{C}$; and a final extension cycle of $30 \mathrm{~min}$ at $60^{\circ} \mathrm{C}$.

For analysis, the techniques of Bakkeren et al. (5) were followed except that only two differently labeled fluorescent AFLP products (6-FAM and JOE) were used. AFLP fingerprints were compared and polymorphisms were scored as 1 (presence of fragment peak) or 0 (absence of fragment peak).

TABLE 2. Inter-simple sequence repeat (ISSR) primers used in developing DNA profiles of different isolates of Ustilago spp.

\begin{tabular}{lccc}
\hline $\begin{array}{l}\text { ISSR } \\
\text { primer no. }\end{array}$ & $\begin{array}{c}\text { Primer sequence } \\
\left(5^{\prime} \text { to } 3^{\prime}\right)^{\mathrm{a}}\end{array}$ & $\begin{array}{c}\text { Working annealing } \\
\text { temperature }\left({ }^{\circ} \mathrm{C}\right)\end{array}$ & $\begin{array}{c}\text { Working DNA } \\
\text { concentration }(\mathrm{ng} / \mu \mathrm{l})\end{array}$ \\
\hline $2^{\mathrm{b}}$ & DVD[AAG]5 & 45 & 20 \\
7 & HBH[GCC]5 & 60 & 20 \\
$12^{\mathrm{b}}$ & DVD[ATC]5 & 45 & 20 \\
$16^{\mathrm{b}}$ & BDB[ACA]5 & 45 & 20 \\
$17^{\mathrm{b}}$ & VDV[GG]7 & 60 & 20 \\
24 & BHB[GTT]5 & 55 & 60 \\
26 & HVH[TGT]5 & 55 & 60 \\
27 & VHV[GTG]5 & 60 & 50 \\
29 & BDB[CCA]5 & 60 & 50 \\
31 & HBH[AGC]5 & 55 & 50 \\
32 & DBD[AAC]5 & 60 & 60 \\
\hline
\end{tabular}

a Single-letter abbreviations for mixed base positions: B = C, G, or T, not A; $\mathrm{D}=\mathrm{A}, \mathrm{G}$, or $\mathrm{T}$, not $\mathrm{C} ; \mathrm{H}=\mathrm{A}, \mathrm{C}$, or $\mathrm{T}$, not $\mathrm{G} ; \mathrm{V}=\mathrm{A}, \mathrm{C}$, or $\mathrm{G}$, not $\mathrm{T} ; 5$ or 7 indicates the number of repeats.

${ }^{\mathrm{b}}$ Excluded from the analysis of all 54 isolates (Table 1). 
Data analysis. A matrix of squared distances between pairs of isolates was constructed from the ISSR data. This was used to determine the average distance within and between species of Ustilago, and to generate a dendrogram based on average linkage using the SAS procedures Cluster and Tree (SAS 2000; SAS Institute, Cary, NC). The squared distance was computed as the number of different bands between the two isolates divided by the total number of polymorphic bands (simple matching).

Parsimony analysis of the various data sets in phylogenetic analysis using parsimony (PAUP) software (42) was used as a phylogenetic inference method. Heuristic searches with random stepwise addition and 10 replicates were performed (MAXTREES set at 100). Trees were rooted through the outgroup, $U$. nuda. The bootstrap analysis was done using the full heuristic search option (50\% majority rule consensus tree after 100 or 1,000 bootstrap replicates).

\section{RESULTS}

Thirty-one ISSR primers were tested singly using the DNA from a small number of isolates of different Ustilago spp. to determine which primers resulted in a clear banding pattern in agarose gels and yielded polymorphisms among the different species. From these, 11 primers were selected (Table 2). Not all primers gave results with the DNA of all the isolates. In some

TABLE 3. Sixteen isolates of Ustilago spp. used for amplified fragment length polymorphism analysis

\begin{tabular}{|c|c|c|}
\hline Isolate no. & Ustilago spp. & Origin \\
\hline 75 & U. hordei & United States of America \\
\hline 76 & U. hordei & Manitoba, Canada \\
\hline 77 & U. hordei & Manitoba, Canada \\
\hline 78 & U. hordei & Kenya \\
\hline 79 & U. hordei & Ethiopia \\
\hline 80 & U. nigra & Manitoba, Canada \\
\hline 81 & U. nigra & Miles, Turkey ${ }^{\mathrm{a}}$ \\
\hline 82 & U. nigra & Manitoba, Canadab \\
\hline 83 & U. nigra & Manitoba, Canada \\
\hline 84 & U. nigra & Manitoba, Canada ${ }^{\mathrm{c}}$ \\
\hline 85 & U. nigra & Manitoba, Canada ${ }^{\mathrm{c}}$ \\
\hline 86 & U. nigra & France \\
\hline 87 & U. aegilopsidis & Turkey \\
\hline $6^{\mathrm{d}}$ & U. nuda & Lacombe, Alberta, Canada, 1996 \\
\hline $42^{\mathrm{d}}$ & U. avenae & United States of America \\
\hline $54^{\mathrm{d}}$ & U. kolleri & Vinton, Quebec, Canada, 1945 \\
\hline
\end{tabular}

instances, no bands were produced with certain isolates using certain primers. Because of this, two sets of data were analyzed. In the first data set, the data from 11 primers scored for 35 isolates were used; in the second data set, the data from 7 primers for 54 isolates were used (Tables 1 and 2). This allowed us to determine if the results changed because of fewer isolates or fewer primers.

Amplification of the DNA from 35 isolates of Ustilago with the 11 ISSR primers resulted in the scoring of 205 polymorphic bands, and the amplification of the DNA from 54 Ustilago isolates with the 7 ISSR primers resulted in the scoring of 137 polymorphic bands.

The average squared distances between isolates within and between the same species of Ustilago for the 35 isolates and 11 ISSR primers data set and the 54 isolates and 7 ISSR primers data set are presented in Table 4. In general, the average squared distance between isolates within a species and between different species was similar for both data sets. The average squared distance between isolates within a species was 10 to $25 \%$ of the average squared distance between species. This was true for all species except for $U$. bullata, in which the average squared distance between isolates was higher and similar to the distances between species when compared with the other species of Ustilago. The average squared distance between $U$. avenae and $U$. kolleri, and between $U$. hordei and U. nigra, were much lower than the distances between other species of Ustilago. In both of these comparisons, the average squared distance between the different species was more similar to the distances obtained when comparing isolates within a species than when comparing between species, especially for $U$. avenae and $U$. kolleri.

The dendrograms produced using the distance matrix based on simple matching for the 35 isolates by 11 primer data sets and the 54 isolates by 7 primer data sets were similar (Figs. 1 and 2). In both figures, there are seven clusters in which the average distance between isolates within the clusters is less than $0.1(10 \%$ of the bands are different), but the difference between each pair of clusters is more than 0.2 ( $>20 \%$ of the bands are different). Of the seven clusters, three are composed of isolates of $U$. bullata, one is $U$. nuda, one is $U$. tritici, one is $U$. nigra and U. hordei, and one is $U$. avenae and $U$. kolleri. The $U$. nigra/U. hordei and the $U$. avenae/U. kolleri clusters are the most similar. The three clusters of $U$. bullata suggest that these isolates are not as closely related as the isolates within the other species. It appears that Ub70, $\mathrm{Ub72}, \mathrm{Ub71}$, and Ub73 are more closely related to the isolates of the other Ustilago spp. than to Ub69. The difference between the two dendrograms is whether the $U$. nuda cluster or the four isolates of $U$. bullata (Ub70, Ub72, Ub71, and Ub73) join the clusters of the other species of Ustilago first. Although Figures 1 and 2 differ in this regard, the actual differences in average distance between clusters between these figures is small.

TABLE 4. Average squared distance within and between species of Ustilago based on simple matching using ungrouped bands (each band counted once)

\begin{tabular}{|c|c|c|c|c|c|c|c|}
\hline \multirow[b]{2}{*}{ Ustilago spp. } & \multicolumn{7}{|c|}{ Average squared distance ${ }^{\mathrm{a}}$} \\
\hline & U. avenae & U. bullata & U. hordei & U. kolleri & U. nigra & U. nuda & U. tritici \\
\hline Within species & 0.023 & 0.277 & 0.055 & 0.024 & 0.025 & 0.028 & 0.025 \\
\hline U. avenae & & 0.342 & 0.239 & 0.026 & 0.245 & 0.359 & 0.301 \\
\hline U. hordei & 0.232 & 0.369 & $\ldots$ & 0.231 & 0.085 & 0.306 & 0.302 \\
\hline U. kolleri & 0.022 & 0.373 & 0.223 & $\ldots$ & 0.236 & 0.357 & 0.308 \\
\hline U. nigra & 0.237 & 0.373 & 0.068 & 0.227 & $\ldots$ & 0.317 & 0.318 \\
\hline No. of isolates ${ }^{b}$ & $5 / 8$ & $5 / 5$ & $5 / 10$ & $5 / 9$ & $5 / 8$ & $5 / 5$ & $5 / 9$ \\
\hline
\end{tabular}

a Values in above diagonal are from data obtained from 35 isolates of Ustilago spp. using 11 inter-simple sequence repeat (ISSR) primers, and values in below diagonal are from data obtained from 54 isolates of Ustilago spp. and 7 ISSR primers.

${ }^{\mathrm{b}}$ The first value in the number of isolates represents the number of isolates used for the 35 isolates of Ustilago and the second value represents the number of isolates used for the 54 isolates of Ustilago. 
PAUP analysis of the data set generated with 35 Ustilago isolates and 11 ISSR primers resulted in the phylogenetic tree presented in Figure 3. PAUP analysis of the data set generated with 54 Ustilago isolates and 7 ISSR primers resulted in a phylogentic tree as presented in Figure 4. In both Figures 3 and 4, the $U$. nuda isolates are in a cluster and are separated from the rest of the Ustilago spp. According to the majority rule and bootstrap analysis, four of the isolates form a monophyletic cluster and one isolate (Unu4) varies from the other four, although not significantly so far as the bootstrap analysis is concerned in Figure 4. The next cluster is of the $U$. bullata isolates, which in this alternative analysis also isolates Ub69 but, once again, not significantly according to bootstrap analysis. The isolates of $U$. tritici cluster well together and the majority rule and bootstrap analyses suggest that they form a monophyletic group. Two more major clusters are formed in Figures 3 and 4, one of which contains the isolates of $U$. nigra and $U$. hordei and the other the isolates of $U$. avenae and $U$. kolleri. The majority rule and bootstrap analyses indicate that the cluster including the isolates of $U$. avenae and $U$. kolleri separates well from the isolates of the other Ustilago spp. but, within this cluster, the isolates of $U$. avenae and the isolates of $U$. kolleri are not separated into species-specific clusters. The majority rule and bootstrap analyses indicate that the U. nigra and $U$. hordei cluster separate well from the isolates of other Ustilago spp. In both Figures 3 and 4, the majority rule analysis separate the isolates of $U$. nigra into one cluster and the $U$. hordei isolates into another cluster and the bootstrap analysis values are moderately high (74 to $88 \%$ ). Although, in both figures, the bootstrap analysis is significant for the $U$. nigra cluster, it is not significant for the $U$. hordei cluster, suggesting that these clusters are different, but the differences are not great.

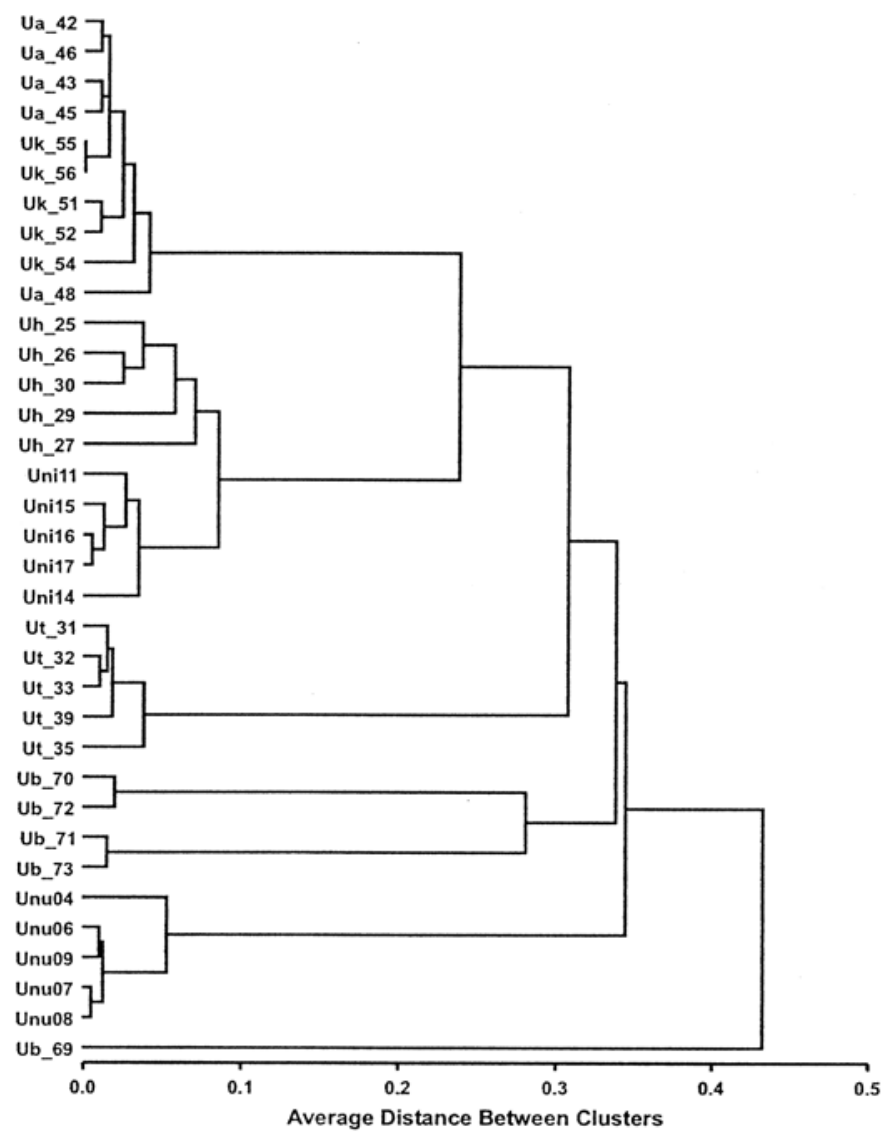

Fig. 1. Dendrogram of average distance (based on simple matching) between clusters for 35 isolates of small grain Ustilago spp. analyzed using 11 intersimple sequence repeat primers.
Four primer pair combinations yielded AFLP fingerprints from which a binomial data set is derived with a total of 136 characters (bands or fragments), of which 75 were parsimony-informative (polymorphic fragments) and 61 parsimony-uninformative. When $U$. nuda is treated as an "outgroup", three clusters can be distinguished (Fig. 5). One consists of the species $U$. avenae and $U$. kolleri, both pathogenic on Avena spp.; one encompasses $U$. aegilopsidis, pathogenic on Aegilops; and one is a smut isolated from Aegilops caudata (from Turkey) which previously had been identified as $U$. nigra. The third cluster consists of all the other $U$. hordei and $U$. nigra geographic isolates found on Hordeum vulgare (except for strain $U$. nigra 82 which was isolated from $H$. agriocrithon). In this third cluster, the $U$. hordei and $U$. nigra isolates are interspersed and the bootstrap analysis does not support the existing "species" boundaries.

\section{DISCUSSION}

The analysis of the two data sets (Table 4; Figs. 1 to 4) separated the isolates of $U$. nuda, U. tritici, U. hordei, U. nigra, $U$. avenae, and $U$. kolleri into four major clusters. The isolates of the two floral-infecting smuts, $U$. nuda and $U$. tritici, each formed their own cluster; the two seedborne smuts of barley, $U$. hordei and $U$. nigra, formed a third major cluster; and the two seedborne smuts of oat, $U$. avenae, and $U$. kolleri, formed a fourth major cluster. The isolates of the seedborne $U$. bullata were well separated from the other Ustilago spp., but did not group well together and seemed to form one to three separate clusters.

The development of two data sets in which the number of isolates of Ustilago and the number of primers used to analyze the DNA differed did not appear to affect the results of these experiments. The only difference of note between these two data sets

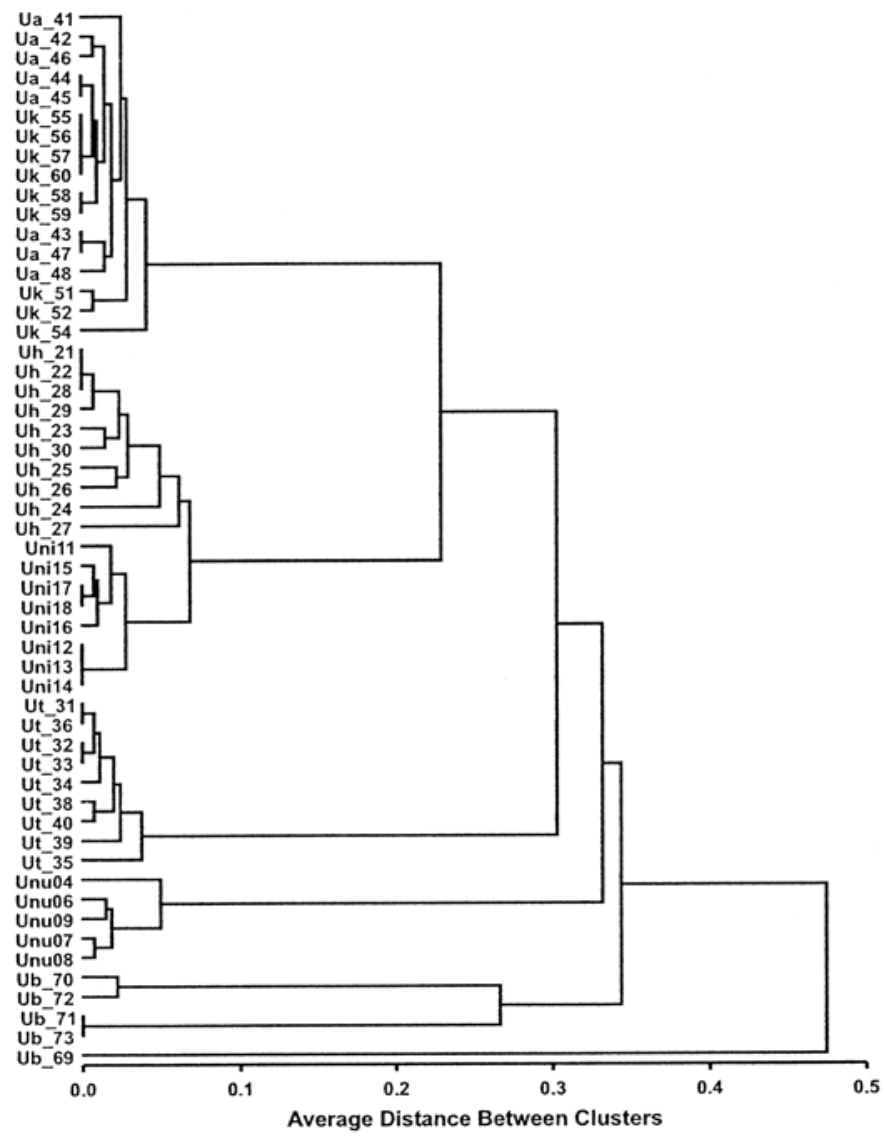

Fig. 2. Dendrogram of average distance (based on simple matching) between clusters for 54 isolates of small grain Ustilago spp. analyzed using seven inter-simple sequence repeat primers. 
occurred in the dendrograms of average distance between clusters in Figures 1 and 2. In Figure 1 (35 isolates and 11 ISSR primers), the cluster of $U$. bullata isolates falls between the cluster of $U$. tritici isolates and the cluster of $U$. nuda isolates, whereas in Figure 2 (54 isolates and 7 ISSR primers), the cluster of $U$. nuda isolates is between the $U$. tritici cluster and the $U$. bullata cluster. This is reflected in the weak bootstrap support of the branch $U$. bullata/U. tritici which has been noted before (5). Otherwise, the differences in the average squared distance within and between species (Table 4) and the PAUP analysis (Figs. 3 and 4) between the two data sets are small and have little effect on interpretation of the results of the experiments. The lack of differences between these two data sets is likely a reflection of the number of polymorphic bands found among the isolates within the two data sets. Although only 35 isolates were used with the 11 ISSR primers, there were 205 polymorphic bands among the isolates; whereas, when the 54 isolates were used with only 7 ISSR primers, there were 137 polymorphic bands. Both data sets are adequate given the number of isolates for each species and polymorphic bands in each set.

Several analyses support the notion that $U$. nuda can be treated as an outgroup in these studies (Figs. 3 and 4; data not shown) in which PAUP analyses have been performed while forcing $U$. tritici or $U$. bullata as outgroups (5). Branches for the $U$. nuda cluster are well supported. In addition, the average squared distance analyses indicate that the five $U$. nuda isolates are closely

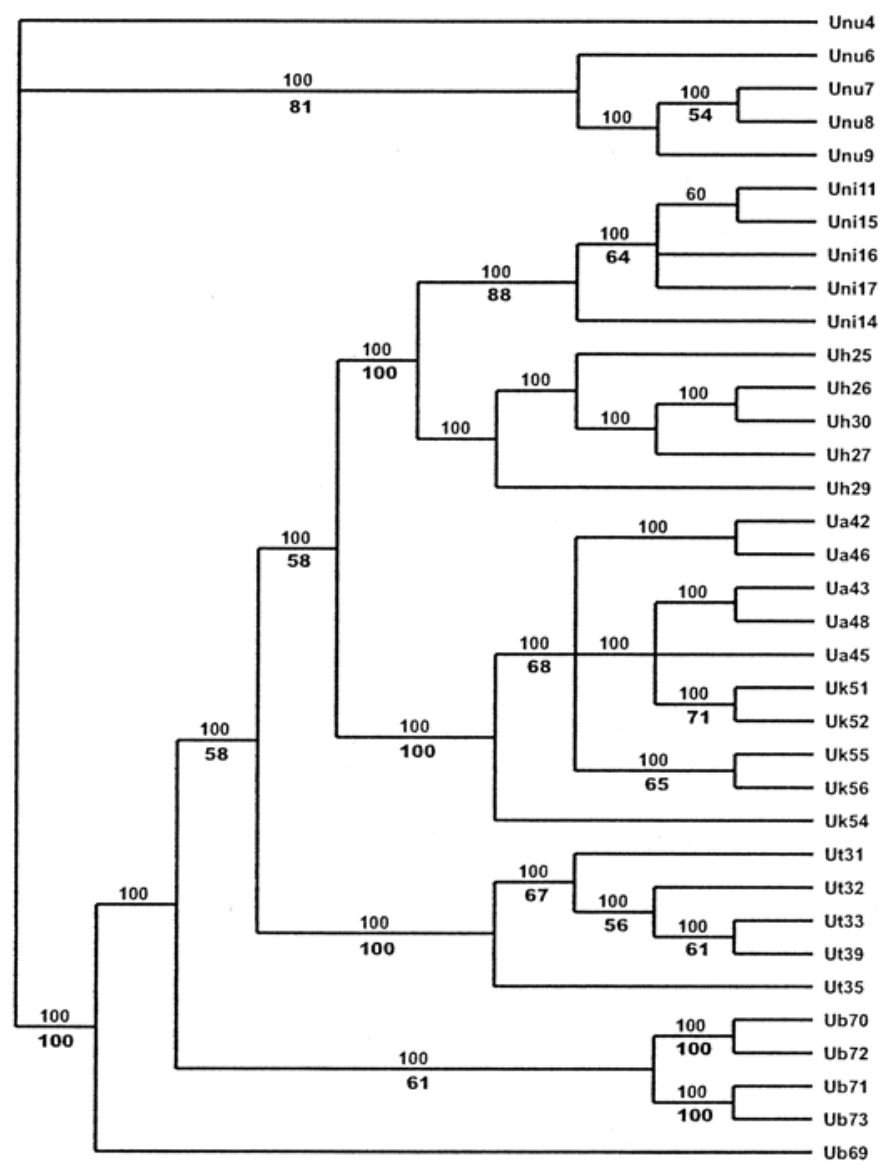

Fig. 3. Phylogenetic relationships among 35 isolates of small grain Ustilago spp. recalculated from analysis using 11 inter-simple sequence repeat primers. The data set harbored 205 characters, of which 168 were parsimony informative, 35 uninformative, and 2 constant. The consensus tree was generated with parsimony analysis (PAUP) using the heuristic search option (CI of 0.556 , RI of 0.849 , and a mean tree length of 365). Numbers above branches indicate consensus in percent (50\% majority rule), bold numbers below branches refer to bootstrap values in percent after 100 replicates (full heuristic search option). related and form a monophyletic group (Table 4). The data analysis in this study seems to indicate that, on a relative basis, $U$. nuda is the least closely related to any of the other six Ustilago spp. Our data would support the separation of $U$. nuda from the other species in this study as a separate species.

The other floral-infecting smut isolates of Ustilago (i.e., the $U$. tritici isolates) also were found to form a monophyletic group. These isolates had a small average squared distance within the $U$. tritici species (Table 4) and their branching was well supported (Figs. 3 and 4). Interestingly, the $U$. tritici isolates seem to be more closely related to the seed-infecting smuts of barley and oat than $U$. nuda and $U$. bullata, although this might not be significant. The data of Bakkeren et al. (5), obtained using AFLP analysis, indicated that $U$. nuda was more closely related to the seedinfecting smuts than $U$. tritici or $U$. bullata. As with $U$. nuda, our data would support the separation of the $U$. tritici isolates as a species.

The separation of the floral-infecting isolates into two separate species, $U$. nuda and $U$. tritici, has not been supported by all researchers. These fungi have been considered to be one species, with specialized forms infecting barley or wheat, by a number of authors of major works on the systematics of the smut fungi, such as Fischer (14), Ainsworth and Sampson (1), Fischer and Shaw (15), Lindeberg and Nannfeldt (25), and Punithalingam and Waterston (39). In general, they classified these fungi into the same species because they concluded that spore morphology and morphological characteristics after spore germination and infection type were identical. Others, in particular Nielsen, have disputed these findings and conclusions. Nielsen (31) agreed that both $U$. tritici and $U$. nuda germinate to form a four-celled promycelium, but argued that their respective promycelia differ in size and shape. The promycelium of $U$. tritici is slightly curved and about twice as long as the straight promycelium of $U$. nuda. In $U$. tritici, Nielsen found that each promycelial cell grows into a curved monokaryotic, haploid hypha, and compatible hyphae may fuse later to form dikaryons, each of which divides again into one dikaryon and two curved monokaryons. In $U$. nuda, however, Nielsen found that two dikaryons are formed by fusion of compatible promycelial cells. The dikaryons then divide again into one dikaryon and two monokaryons, each forming a mass of hyphae devoid of the regularity that is displayed by $U$. tritici. In addition, even though the two species have a compatible bipolar mating system, $U$. nuda has some peculiarities that separate its lines of different mating types from lines of $U$. tritici with the same mating types. Nielsen (29) found that all of the $U$. nuda lines with mating type $1(M A T-1$, formerly called $a)(3,4)$ have a proline deficiency when grown on minimal medium and the gene controlling the proline synthesis in these lines is linked to the matingtype locus. It was also found that lines of $U$. nuda with mating type $2(M A T-2$, formerly called $A)(3,4)$ are temperature sensitive, while those of $U$. tritici are not. Nevertheless, monokaryotic lines of certain races of the two species can be hybridized to form $F_{1}$ spores, but future generations from these spores are not viable (34).

The above-mentioned differences in spore morphology and characteristics of the fungi after spore germination are not the only characteristics that can be used to differentiate the fungi that cause loose smut of wheat from those that cause loose smut of barley. $U$. nuda and $U$. tritici share some of the same hosts, but $U$. $n u d a$ has a narrower host range than $U$. tritici (34). In addition, sori of $U$. nuda are always initially covered with a thin membrane, whereas those of $U$. tritici are always naked (34). The two fungi also can be differentiated by detergent-soluble polypeptides (23), soluble protein extracts (12), and DNA analysis (5). Kim et al. (23) found that $U$. nuda and $U$. tritici differed by 47 polypeptides, with $U$. tritici having 30 polypeptides which were absent in $U$. nuda and $U$. nuda having 17 which were absent in $U$. tritici. Dutrecq and Farro (12) reported that, when soluble protein 
extracts were run using cellulose acetate electrophoresis, the two forms differed by at least one fast-moving protein band. Bakkeren et al. (5) compared the use of DNA sequences from the genomic ITS ribosomal RNA region with AFLP to distinguish among species and isolates from the Ustilaginomycetes. They found very little nucleotide variation among the ITS DNA sequences of the small grain-infecting smuts, implying a lack of differentiation and, therefore, a close relationship among the different species studied. Nevertheless, they were able to distinguish among the different species of Ustilaginomycetes, except for $U$. nigra and $U$. hordei, with $U$. tritici and $U$. nuda being distinctly different from each other. The AFLP analysis was able to separate all eight smut species they examined ( $U$. aegilopsidis was included with the isolates of the seven Ustilago spp.) (5) and, once again, there was a clear separation between $U$. tritici and $U$. nuda. Given the data presented in this study and the findings of others listed above, we would conclude that $U$. nuda and $U$. tritici are two separate species.

Some speculation has occurred on the relationships between $U$. tritici and $U$. nuda as to their mode of origin. Becerescu (7) suggested that $U$. nuda arose from $U$. nigra and $U$. tritici arose from either $U$. nuda or $U$. nigra. The germination type of $U$. tritici is intermediate between $U$. nuda and sporidial types like $U$. nigra (31). However, Nielsen (34) suggested that, because $U$. nuda has a narrower host range and is more specialized than $U$. tritici, $U$. nuda may have arisen from $U$. tritici. If, however, broadening a

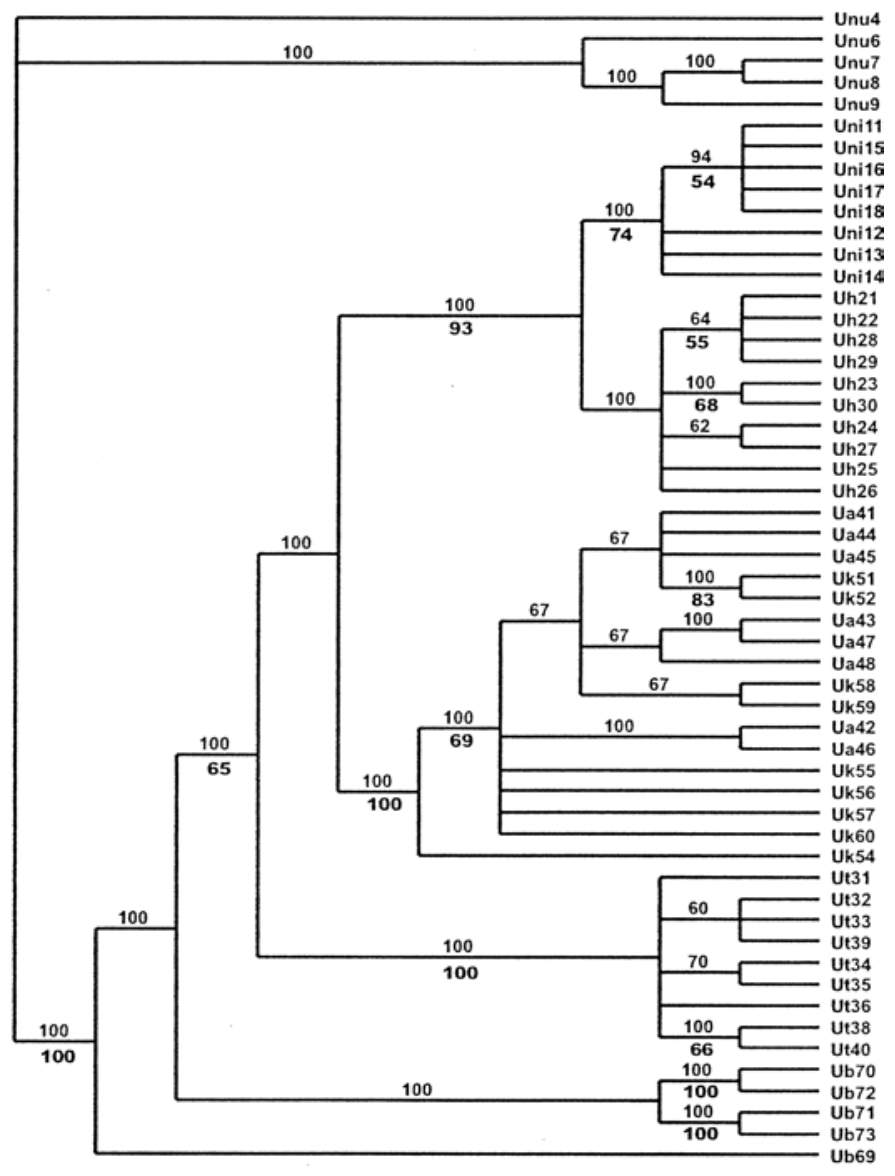

Fig. 4. Phylogenetic relationships among 54 isolates of small grain Ustilago spp. recalculated from analysis using seven inter-simple sequence repeat primers. The data set harbored 137 characters, of which 114 were parsimonyinformative, and 23 uninformative. The consensus tree was generated with parsimony analysis (PAUP) using the heuristic search option (CI of 0.500 , a RI of 0.871 , and a mean tree length of 274). Numbers above branches indicate consensus in percent (50\% majority rule), bold numbers below branches refer to bootstrap values in percent after 100 replicates (full heuristic search option). host range on related hosts is caused by the acquisition of virulence factors which might be equivalent to the loss of mutation of avirulence factors, one could argue that $U$. tritici evolved from $U$. nuda. Our results with the seven Ustilago spp. included in this study indicate that $U$. tritici and $U$. nuda are not closely related to $U$. nigra, although $U$. tritici does appear to be more closely related to $U$. nigra compared with $U$. nuda and $U$. nigra. This is in contrast to the work of Bakkeren et al. (5), who found that $U$. $n u d a$ was more closely related to $U$. nigra, U. hordei, U. avenae, and $U$. kolleri than was $U$. tritici, using ITS and AFLP data. The reasons for these differences between the results of Bakkeren et al. (5) and those presented here are not clear, except that more isolates of the different Ustilago spp. were used here. Also of interest in our results is the fact that $U$. bullata appeared to be an intermediate type between $U$. tritici and $U$. nuda (Figs. 1, 3, and 4). In the work of Bakkeren et al. (5), U. bullata and U. tritici were more closely related to each other than to $U$. nuda, although it was not a strong relationship. However, as Bakkeren et al. (4) suggest, it is tempting to speculate that even though $U$. nuda and $U$. tritici are both embryo-infecting smuts, this mode of infection may have arisen separately in these two species. Certainly, from our data, $U$. bullata seems to be an intermediate species between $U$. nuda and $U$. tritici.

The $U$. bullata isolates did not form a strong monophyletic group. The average squared distance among isolates of $U$. bullata was high and not comparable to the distances among isolates

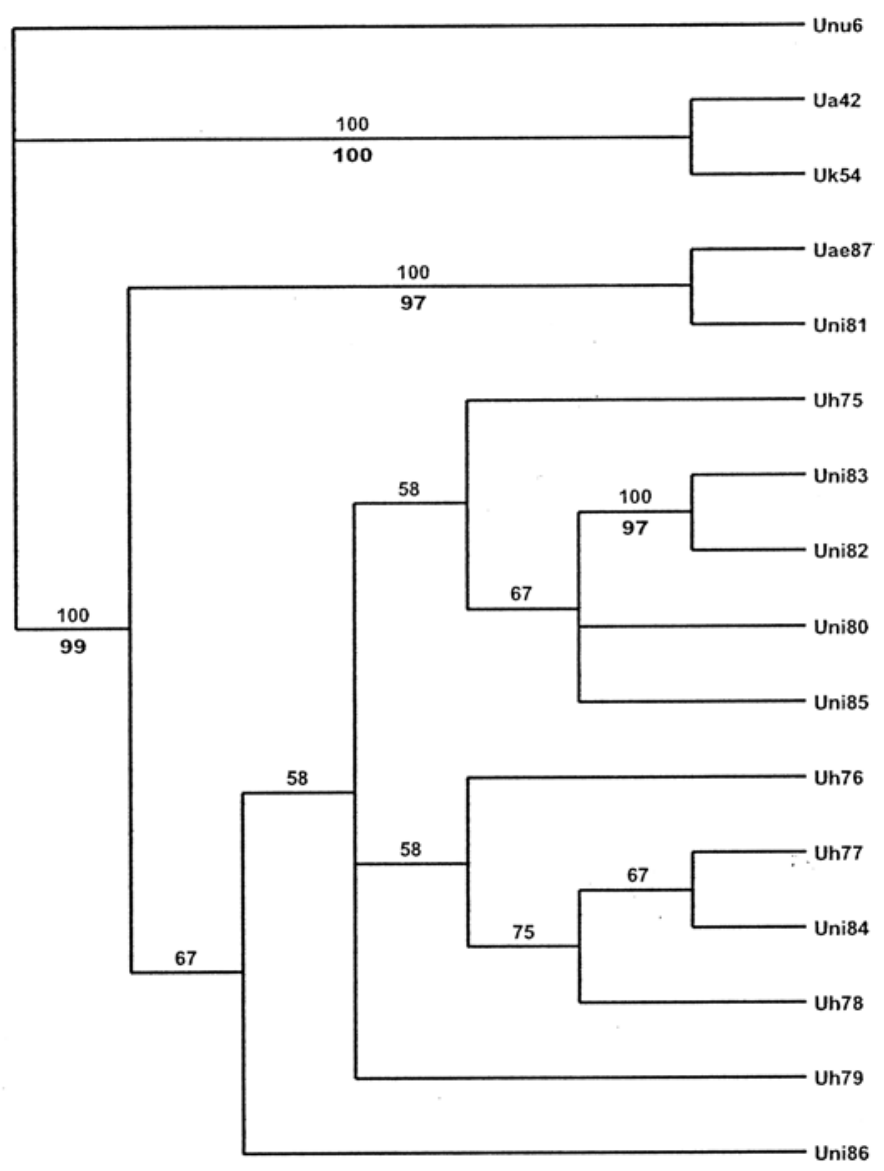

Fig. 5. Phylogenetic relationships among different small grain-infecting smut isolates calculated from amplified fragment length polymorphisms. The consensus tree was generated with parsimony analysis (PAUP) using the heuristic search option; Ustilago nuda 96-253 (U nu) was designated outgroup. Numbers above branches indicate consensus in percent ( $50 \%$ majority rule), bold numbers below branches refer to bootstrap values in percent after 1,000 replicates (full heuristic search option, giving a mean tree length of 214 , a CI of 0.636 , and a RI of 0.642). 
within species for the other Ustilago spp. (Table 4). This is corroborated in Figures 1 and 2, where the $U$. bullata isolates appear to be in three clusters, and in Figures 3 and 4, with high bootstrap support for branching within the cluster and the separation of isolate 69 of $U$. bullata. When grown in shake culture, isolate Ub69 produces round sporidia, while the other isolates produce oval sporidia (F. Matheson, unpublished data), also suggesting differences among the isolates. If the analysis in Table 4 is repeated while omitting Ub69, the average squared distances within the species ( $U$. bullata) is reduced by 30 to $35 \%$ for both data sets $(0.193$ for the 35 isolates by 11 ISSR primers data set and 0.181 for the 54 isolates by 7 ISSR primers data set). This still is not comparable to the within-species values obtained for the other Ustilago spp. (0.019 to 0.055). The values obtained for the average squared distances among $U$. bullata and the other species also were reduced by $\approx 5$ to $10 \%$ when Ub69 was omitted from the data sets, but this reduction did not affect the results of the analyses. Our data suggest that $U$. bullata is a more variable species than the other Ustilago spp. studied. Certainly, U. bullata has a wide host range, infecting species of Gramineae including Agropyron, Brachypodium, Bromus (including Zerna), Elymus (including Clinelymus), Festuca, Hordeum, Lolium, and Sitanion (46), and isolates of $U$. bullata often differ in host pathotypes $(13,27)$. The isolates used in this study were isolated from Downy Brome (Bromus tectorum L, isolates Ub69 and Ub70), Foxtail Barley (Hordeum jubatum L, isolates Ub71 and Ub73), and Meadow Brome (B. riparius Rehmann, isolate Ub72). Turnbull and Gossen (44) found that the Saskatchewan and Alberta, Canada, populations of $U$. bullata were composed of three groups of pathotypes with specific hosts that did not necessarily overlap, suggesting a large degree of variability in these populations. In addition, Kirby and Mulley (24) found that, when they crossed two races of $U$. bullata, there was a high degree of inviability of primary sporidia from the hybrid teliospores. The variability among the $U$. bullata isolates in this manuscript also may be caused by not all the isolates being $U$. bullata, or the species being not well characterized. However, the $U$. bullata isolates as a group are well separated from the other Ustilago spp.

The last two clusters are composed of the seedling-infecting smut species $U$. nigra, U. hordei, U. avenae, and U. kolleri. These species separate into two significantly different clusters; one is composed of the oat-infecting $U$. avenae and $U$. kolleri, and the other is composed of the barley-infecting $U$. nigra and $U$. hordei. From our data, it appears that $U$. avenae and $U$. kolleri are very similar and likely monophyletic. The average squared distances between the two species are essentially the same as within the individual species (Table 4) and the isolates of the two species are well interspersed within the major cluster (Figs. 1 and 2). In addition, in the PAUP analysis, support for branching between $U$. avenae and $U$. kolleri isolates is weak.

The $U$. nigra and $U$. hordei isolates also appear to be closely related to each other but perhaps not as closely as the isolates of $U$. avenae and $U$. kolleri. The average squared distances between the $U$. nigra and the $U$. hordei isolates and the average distance between clusters were larger than those among the isolates within each species (except for U. bullata; Table 4; Figs. 1 to 3), but still small, suggesting a close relationship. This close relationship was also revealed in the dendrogram constructed from the AFLP data (Fig. 5). The U. nigra and $U$. hordei isolates cluster together using this analysis technique, and they appear to be monophyletic. However, in the ISSR analysis, U. nigra and U. hordei formed individual small clusters within the large cluster with supported branches (Figs. 3 and 4).

As previously mentioned, Stevenson and Johnson (41) proposed a nomenclature system in which the causal agents of loose and covered smut of oat and false loose and covered smuts of barley were separately classified as U. avenae, U. kolleri, U. nigra, and $U$. hordei, respectively. However, Fischer (14), Ainsworth and
Sampson (1), and Vánky (46) reduced this group of fungi to two species based on spore morphology. In their systems, the echinulate spore types are united under the name of $U$. avenae, eliminating $U$. nigra, and the smooth spore types are united under $U$. hordei, eliminating U. kolleri. Lindeberg and Nannfeldt (25) went even further in reducing the number of species of Ustilago among this group by reducing these fungi to one species, $U$. segetum (Bull.:Pers.) Roussel, with two morphological distinct forms as varieties of this taxon, $U$. segutum var. avenae (Pers.) Brun which has echinulate spores, and $U$. segutum var. hordei (Pers.) Rbh., which has smooth spores. Support for the onespecies concept of Lindeberg and Nannfeldt can be found in the ability of all four species to readily hybridize among themselves. It would appear from the work presented in this study and others that to delimit two morphologically distinct species on barley and two on oat does not appear to be tenable, and to classify these fungi based on spore morphology also does not appear to be tenable (21).

The taxonomic relationships among $U$. avenae, $U$. kolleri, $U$. nigra, and $U$. hordei are very close. All four species have been successfully hybridized with each other, indicating a close taxonomic relationship, but the only interspecific cross in which lysis has not been encountered is $U$. nigra $\times U$. hordei (30), suggesting that these two species are closer to each other than to $U$. avenae or $U$. kolleri. The four species also share genes for spore echinulation. Studies have shown that echinulation of the spores in these four species are controlled by the same two dominant and complimentary genes $(21,28,43)$. Perhaps this indicates that spore morphology should not be considered in determining species differences among these fungi because it represents only a small genetic difference among these four species of Ustilago. There also are similarities within particular pairs of these four species of Ustilago. U. avenae and $U$. kolleri have very similar host ranges (37) and share a recessive gene for buff teliospore color (28). $U$. hordei and $U$. nigra have been shown to possess identical genes for virulence to the barley cultivars Keystone and Conquest (16). Kim et al. (23) also were able to show differences and similarities among these four species through analysis of detergent-soluble polypeptides. They found that $U$. avenae and $U$. kolleri differed in only one peptide, indicating a very close relationship, and $U$. nigra and $U$. hordei differed in only six polypeptides. A comparison of $U$. avenae and $U$. kolleri with $U$. nigra and $U$. hordei indicated that these two groups differed by only seven polypeptides. They concluded that their work supported the proposal by Lindeberg and Nannfeldt (25) that the four species should be united under $U$. segetum. Bakkeren et al. (5) studied these four species using the DNA sequences from the ITS ribosomal RNA region and the AFLP technique. As was seen in our data, they found that $U$. avenae and $U$. kolleri clustered together (although only one isolate of each species was analyzed) and U. nigra and $U$. hordei clustered together. The differences between these two clusters were significant in both cases. Bakkeren et al. (5) suggested that these four species of fungi could be combined into $U$. segetum var. avenae, which would contain $U$. avenae and $U$. kolleri, and into U. segetum var. hordei, which would contain $U$. hordei and $U$. nigra, where the variety name would reflect the economically most important host species. Although our data are similar to those of Bakkeren et al. (5), they may not support the idea of one species (U. segetum) with two varieties (var. avenae and var. hordei). We suggest that $U$. avenae and $U$. kolleri be united under one species, $U$. avenae; $U$. hordei and $U$. nigra would be united under another species, $U$. hordei.

The use of molecular data in taxonomic studies can be very useful. For organisms such as the smut fungi, where few morphological features are available to use in taxonomy studies, the data can be invaluable. The ISSR and AFLP analysis of the seven smut species was useful in determining genetic variability among these species and the results were similar to those obtained by others 
$(5,23)$. The AFLP technique appeared to be more sensitive to differences in DNA sequences and provided more information on the variation between the different isolates than did the ISSR technique. However, the two techniques are complimentary. Establishing species boundaries from DNA polymorphisms should be done cautiously, however, and only with additional characteristics such as morphology, mating compatibilities, and life histories.

\section{ACKNOWLEDGMENTS}

Cereal Research Centre contribution 1828. We thank J. Nielsen and P. L. Thomas for their work and helpful discussion, without which this study might not have been done; and B. McCallum, D. Somers, and A. Tekauz for their constructive comments.

\section{LITERATURE CITED}

1. Ainsworth, G. C., and Sampson, K. 1950. The British Smut Fungi (Ustilaginales). The Commonwealth Mycological Institute, Kew, Surrey, UK.

2. Atlas, R. M., and Parks, L. C. 1993. Handbook of Microbiological Media. CRC Press, Boca Raton, FL.

3. Bakkeren, G., and Kronstad, J. W. 1993. Conservation of the $b$ mating type gene complex among bipolar and tetrapolar smut fungi. Plant Cell 5:123-136.

4. Bakkeren, G., and Kronstad, J. W. 1994. Linkage of mating-type loci distinguishes bipolar from tetrapolar mating in Basidiomycetous smut fungi. Proc. Natl. Acad. Sci. USA 91:7085-7089.

5. Bakkeren, G., Kronstad, J. W., and Lévesque, C. A. 2000. Comparison of AFLP fingerprints and ITS sequences as phylogenetic markers in Ustilaginomycetes. Mycologia 92:510-521.

6. Bauer, R., Oberwinkler, F., and Vánky, K. 1997. Ultrastructural markers and systematics in smut fungi and allied taxa. Can. J. Bot. 75:12731314.

7. Becerescu, D. 1967. On the phylogenetic relationships between the species of Ustilago parasitic on barley, wheat and rye. Rev. Roum. Biol. Bot. 12:391-396.

8. Begerow, D., Bauer, R., and Oberwinkler, F. 1997. Phylogenetic studies on nuclear large subunit ribosomal DNA sequences of smut fungi and related taxa. Can. J. Bot. 75:2045-2056.

9. Blanz, P. A., and Gottschalk, M. 1984. A comparison of 5S ribosomal RNA nucleotide sequences from smut fungi. Syst. Appl. Microbiol. 5:518-526.

10. Bradford, L. S., Jones, R. J., and Garber, E. D. 1975. An electrophoretic survey of fourteen species of the fungal genus Ustilago. Bot. Gaz. 136:109-115

11. Charlesworth, B., Sniegowski, P., and Stephan, W. 1994. The evolutionary dynamics of repetitive DNA in eukaryotes. Nature 371:215-220.

12. Dutrecq, A., and Farro, A. 1971. Differenciation des formes physiologiques du charbon nu des céréales (Ustilago nuda (Jens.) Rostr. et Ustilago nuda f. tritici (Jens.) Schaff.) par électrophorése sur acétate de cellulose. Meded. Fac. Landbouwwet. Rijksuniv. Gent. 36:997-1000.

13. Fischer, G. W. 1940. Host specialization in the head smut of grasses, Ustilago bullata. Phytopathology 30:991-1017.

14. Fischer, G. W. 1943. Some evident synonymous relationships in certain graminicolous smut fungi. Mycologia 35:610-619.

15. Fischer, G. W., and Shaw, C. G. 1953. A proposed species concept in the smut fungi with application to North American species. Phytopathology 43:181-188.

16. Fullerton, R. A., and Nielsen, J. 1974. Identical genes for virulence in the smuts Ustilago hordei and U. nigra and inheritance of virulence on the barley cultivars Keystone and Conquest. Can. J. Plant Sci. 54:253257.

17. Gang, D. R., and Weber, D. J. 1996. Using random amplified polymorphic DNA to analyze the genetic relationships and variability among three species of wheat smut (Tilletia). Bot. Bull. Acad. Sin. 37:173-180.

18. Hanna, W. F., and Popp, W. 1930. Relationship of the oat smuts. Nature 126:843-844.

19. Hantula, J., Dusabenyagasani, M., and Hamelin, R. C. 1996. Random amplified microsatellites (RAMS) - A novel method for characterizing genetic variation within fungi. Eur. J. For. Pathol. 26:159-166.
20. Holton, C. S. 1931. Hybridization and segregation in the oat smuts. Phytopathology 21:835-842.

21. Huang H.-Q., and Nielsen, J. 1984. Hybridization of the seedlinginfecting Ustilago spp. pathogenic on barley and oats, and a study of the genotypes conditioning the morphology of their spore walls. Can. J. Bot. 62:603-608.

22. Kim, W. K., Mauthe, W., Hausner, G., and Klassen, G. R. 1990. Isolation of high molecular weight DNA and double-stranded RNAs from fungi. Can. J. Bot. 68:1898-1902.

23. Kim, W. K., Rohringer, R., and Nielsen, J. 1984. Comparison of polypeptides in Ustilago spp. pathogenic on wheat, barley, and oats: A chemotaxonomic study. Can. J. Bot. 62:1431-1437.

24. Kirby, G. C., and Mulley, A. M. 1982. Inheritance of isozyme mobility differences between two races of the head smut of grasses, Ustilago bullata Berk. Bot. Gaz. 143:243-248.

25. Lindeberg, B., and Nannfeldt, J. A. 1959. Ustilaginales in Sweden (Exclusive of the Cintractias on Caricoideae). Symb. Bot. Ups. 16:14160.

26. Majer, D., Mitten R., Lewis, B. G., Vos, P., and Oliver, R. P. 1996. The use of AFLP fingerprinting for the detection of genetic variation in fungi. Mycol. Res. 100:1107-1111.

27. Meiners, J. P., and Fischer, G. W. 1953. Further studies of host specialization in the head smut of grasses, Ustilago bullata. Phytopathology 43:200-203.

28. Nielsen, J. 1968. The inheritance of spore wall characteristics in Ustilago avenae and U. kolleri. Can. J. Bot. 46:497-500.

29. Nielsen, J. 1968. Isolation and culture of monokaryotic haplonts of Ustilago nuda, the role of proline in their metabolism, and the inoculation of barley with resynthesized dikaryons. Can. J. Bot. 46:11931200 .

30. Nielsen, J. 1968. Experiments on vegetative dissociation of the dikaryon and on lysis of hybrid sporidia of the cross Ustilago avenae $\times$ U. kolleri. Can. J. Bot. 46:487-496.

31. Nielsen, J. 1972. Isolation and culture of monokaryotic haplonts of Ustilago tritici, observations on their physiology, and the taxonomic relationships between $U$. tritici and $U$. nuda. Can. J. Bot. 50:1775-1781.

32. Nielsen, J. 1978. Two grasses as common hosts for all species Ustilago parasitic on wheat, barley, and oats. Can. J. Bot. 56:2712-2716.

33. Nielsen, J. 1985. Ustilago spp. pathogenic on Aegilops. II. Ustilago tritici. Can. J. Bot. 63:765-771.

34. Nielsen, J. 1987. Reactions of Hordeum species to the smut fungi $U$. nuda and U. tritici. Can. J. Bot. 65:2024-2027.

35. Nielsen, J. 1987. Races of Ustilago tritici and techniques for their study. Can. J. Plant Pathol. 9:91-105.

36. Nielsen, J. 1988. Ustilago spp., Smuts. Adv. Plant Pathol. 6:483-490.

37. Nielsen, J. 1993. Host specificity of Ustilago avenae and U. hordei on eight species of Avena. Can. J. Plant Pathol. 15:14-16.

38. Procunier, J. D., Townley-Smith, T. F., Fox, S., Prashar, S., Gray, M., Kim, W. K., Czarnecki, E., and Dyck, P. L. 1995. PCR-based RAPD/DGGE markers linked to leaf rust resistance genes Lr29 and Lr25 in wheat (Triticum aestivum L.). J. Genet. Breed. 49:87-92.

39. Punithalingam, E., and Waterston, J. M. 1970. Ustilago nuda. CMI Descriptions of Pathogenic Fungi and Bacteria, No. 280. Commonw. Mycol. Inst. Surrey, England.

40. Shi, Y. L., Loomis, P., Christian, D., Carris, L. M., and Leung, H. 1996. Analysis of the genetic relationships among the wheat bunt fungi using RAPD and ribosomal DNA markers. Phytopathology 86:311-318.

41. Stevenson, J. A., and Johnson, A. G. 1944. The nomenclature of the cereal smut fungi. Plant Dis. Rep. 28:663-670.

42. Swofford, D. L. 1999. PAUP: Phylogenetic Analysis Using Parsimony. Version 4.0b2. Sinauer Associates, Sunderland, MA.

43. Thomas, P. L. 1989. Genetic modification of echinulation on teliospores of Ustilago hordei and U. nigra hybrids. Bot. Gaz. 150:319-322.

44. Turnbull, G. D., and Gossen, B. D. 1996. Head smut of grasses on the Canadian prairies. II. Host range and variability. Can. J. Plant Pathol. 18:255-260.

45. Vánky, K. 1991. Spore morphology in the taxonomy of the Ustilaginales. Trans. Mycol. Soc. Jpn. 32:381-400.

46. Vánky, K. 1994. European Smut Fungi. Gustav Fischer Verlag. Stuttgart, Germany.

47. Zietkiewicz, E., Rafalski, A., and Labuda, D. 1994. Genome fingerprinting by simple sequence repeat (SSR)-anchored polymerase chain reaction amplification. Genome 20:176-183. 